\title{
Urban Heat Island Intensification during Hot Spells-The Case of Paris during the Summer of 2003
}

\author{
Koen De Ridder ${ }^{1, *}$, Bino Maiheu ${ }^{1}$, Dirk Lauwaet ${ }^{1}$, Ioannis A. Daglis ${ }^{2,3}$, \\ Iphigenia Keramitsoglou ${ }^{2}$, Kostas Kourtidis ${ }^{4}$, Paolo Manunta ${ }^{5}$ and Marc Paganini ${ }^{6}$ \\ 1 VITO—Flemish Institute for Technological Research, B-2400 Mol, Belgium; bino.maiheu@vito.be (B.M.); \\ dirk.lauwaet@vito.be (D.L.) \\ 2 Institute for Astronomy, Astrophysics, Space Applications and Remote Sensing, \\ National Observatory of Athens, 15236 Athens, Greece; iadaglis@phys.uoa.gr (I.A.D.); ik@noa.gr (I.K.) \\ 3 Department of Physics, National and Kapodistrian University of Athens, 15784 Athens, Greece \\ 4 Department of Environmental Engineering, Democritus University of Thrace, 67100 Xanthi, Greece; \\ kourtidi@env.duth.gr \\ $5 \quad$ Planetek Italia, via Massaua, 12-70132 Bari, Italy; manunta@planetek.it \\ 6 European Space Agency, ESRIN, 00044 Frascati, Italy; marc.paganini@esa.int \\ * Correspondence: koen.deridder@vito.be; Tel.: +32-14-336751
}

Academic Editor: Panagiotis Nastos

Received: 28 October 2016; Accepted: 17 November 2016; Published: 24 November 2016

\begin{abstract}
Heat waves are projected to become more frequent, longer-lasting, and intense. At the same time, urban areas are confronted with the urban heat island (UHI) phenomenon, which adds to the thermal stress experienced during hot spells. Focusing on the Paris area during the hot summer of 2003, we investigated the influence of heat waves on UHI intensity, i.e., the urban-rural temperature contrast. In a first step, this was done based on observed temperatures from an urban and a rural site, showing that per ${ }^{\circ} \mathrm{C}$ increase in the daytime temperature, the nighttime UHI intensity increased by $0.086{ }^{\circ} \mathrm{C}$. Recognizing the limited spatial representativeness of the urban experimental site, located in a park, we then performed simulations with an urban climate model, covering the wider Paris area for the summer of 2003. First, a validation was done using the aforementioned temperature measurements to do so. Subsequently, we estimated the sensitivity of the nighttime UHI intensity with respect to the daytime temperature, this time using simulated temperatures of the densely built-up areas in the center of Paris, yielding an increase of UHI intensity of $0.19{ }^{\circ} \mathrm{C}$ per ${ }^{\circ} \mathrm{C}$ increase in the daytime temperature. While these results only apply to the domain and period studied, they do confirm recent reports that the UHI intensity increases during heat waves. The results also show that for the cooler parts of the urban fabric (e.g., parks), the UHI intensification during heat waves is around half of that of the dense urban fabric, thus providing some insights into possible mitigation strategies for the future.
\end{abstract}

Keywords: urban heat island; urban climate modeling; heat wave episode

\section{Introduction}

Global climate projections that consistently point towards an increase in the number, frequency, and intensity of heat waves [1-3] have shown that extremely hot summers such as the one of 2003 in Europe are likely to become fairly common towards the end of the century.

Heat waves claim more victims than any other weather-related disaster [4]. A striking illustration of this stems from the comparison between the death toll attributed to Hurricane Katrina in 2005 (amounting to approximately 1500; see [5]) and those of the European heat wave of 2003 (70,000 reported heat-related deaths; see [6]). Often, the health impact of heat waves is minimized by invoking the "harvesting" phenomenon, i.e., the displacement of mortality by days or weeks. Stated 
otherwise, frail people die prematurely but not by much, as they would have died soon afterwards anyway. However, it has been shown that, whereas minor heat wave episodes do induce a fair share of harvesting, this effect decreases as a function of the heat wave strength [7]. In particular, for the major European heat wave of 2003, it was found that the harvesting effect was modest [8]. Indeed, while of the 15,000 excess deaths occurring in France some 4000 would have died before the end of 2004 in any event, in the absence of the disaster the remaining 11,000 would have lived statistically eight to 11 years longer, thus amounting to an estimated 100,000 lost life-years in France alone [9].

Urban areas, which are now home to the majority of humans, exhibit additional heat stress because of the urban heat island (UHI) effect. Indeed, cities experience air temperatures in excess of rural values, their average nighttime temperatures being higher by a few ${ }^{\circ} \mathrm{C}$, but increasing to $7-8{ }^{\circ} \mathrm{C}$ and more under favorable conditions. Because of this UHI increment, cities are particularly vulnerable to heat waves. In a recent study on Berlin, it was found found that during heat waves, mortality rates were higher in the city, especially in the most densely built-up districts [10]. In a study on Paris [11], it was concluded that, during the heat wave of the summer of 2003, areas exhibiting the highest remotely sensed nighttime infrared surface temperature suffered the highest excess mortality. Also for the 2003 European heat wave, it was found that heat-related excess mortality was especially high in cities, Paris being featured on top with an excess mortality of nearly $140 \%$ during the period of 1-19 August 2003 [12]. Even though this enhanced excess mortality can at least partly be attributed to the vulnerability of the urban population (e.g., a larger share of isolated elderly people), increased mortality has been associated with the urban temperature increment itself [9]. Other studies also have established this combined effect on mortality by ambient conditions (heat exposure) and social vulnerability [13]. More insights regarding the spatial variability of heat mortality are available in [14-20].

In addition, recent studies on cities in the US present evidence that the urban temperature increment itself increases during heat waves. The authors of [21] investigated the impact of the heat wave occurring in the second half of July 1999 in the Midwestern US, with temperatures rising well above $32{ }^{\circ} \mathrm{C}$, which resulted in several hundred excess deaths. During this event, the cities of Chicago and St. Louis were found to be disproportionally hotter than their rural surroundings, i.e., during the heat wave the UHI intensity of these cities was higher than average. The authors of [22] considered a heat wave episode in Baltimore, and they equally found that during the heat wave, the urban-rural temperature contrast itself increased. The authors of $[23,24]$, analyzing measurements in Madison, also noticed an increase in the UHI intensity on hot days.

Here, we tackle a similar research question, i.e., we investigate whether the urban-rural temperature increment gets enhanced during heat waves or not, and to what extent. This is done for the area of Paris (France), using both in situ measurements and model simulation results, for the extended summer (May-September) of 2003. This particular period is characterized by a wide range in temperature conditions, with daytime maximum temperatures down to around $12{ }^{\circ} \mathrm{C}$ on some days in May, and reaching just short of $40^{\circ} \mathrm{C}$ on the hottest days during the first half of August of that year.

The remainder of this paper is organized as follows. Section 2 describes the in situ observational data, which are subsequently used to evaluate the UHI intensity as a function of ambient (background) temperature. Section 3 then introduces a simulation conducted with an urban climate model on the Paris area. After validation, the modeling results are used to extend the observation-based results to the entire urban agglomeration of Paris. Finally, Section 4 presents the conclusions of this study.

\section{Observations}

The observation-based analysis presented here relies on synoptic meteorological data contained in the archives of the National Climatic Data Center (US), from which we extracted data for one urban and one rural location in the Paris region (see station positions in Figure 1). The Paris-Montsouris station (WMO code 071560 ) is taken as representative for urban climate conditions. It is located in the Montsouris Park near the center of Paris, at a position of approximately $48.81^{\circ} \mathrm{N}$ and $2.33^{\circ} \mathrm{W}$. This park 
has a diameter of approximately $400 \mathrm{~m}$, and the station is positioned within the park at more than $100 \mathrm{~m}$ from the nearest edge. Therefore, the representativity of this location for urban conditions is to be considered with caution (more on this below). The Melun-Villaroche station (WMO code 071530) is located at $48.61^{\circ} \mathrm{N}$ and $2.68^{\circ} \mathrm{W}$, which is near a small airfield $8 \mathrm{~km}$ north of the center of Melun, which itself is $35 \mathrm{~km}$ from the city center and $20 \mathrm{~km}$ from the outskirts of Paris. It is located in the middle of agricultural fields and grassland, at a distance of several kilometers from the nearest human settlement, thus constituting a representative rural station.

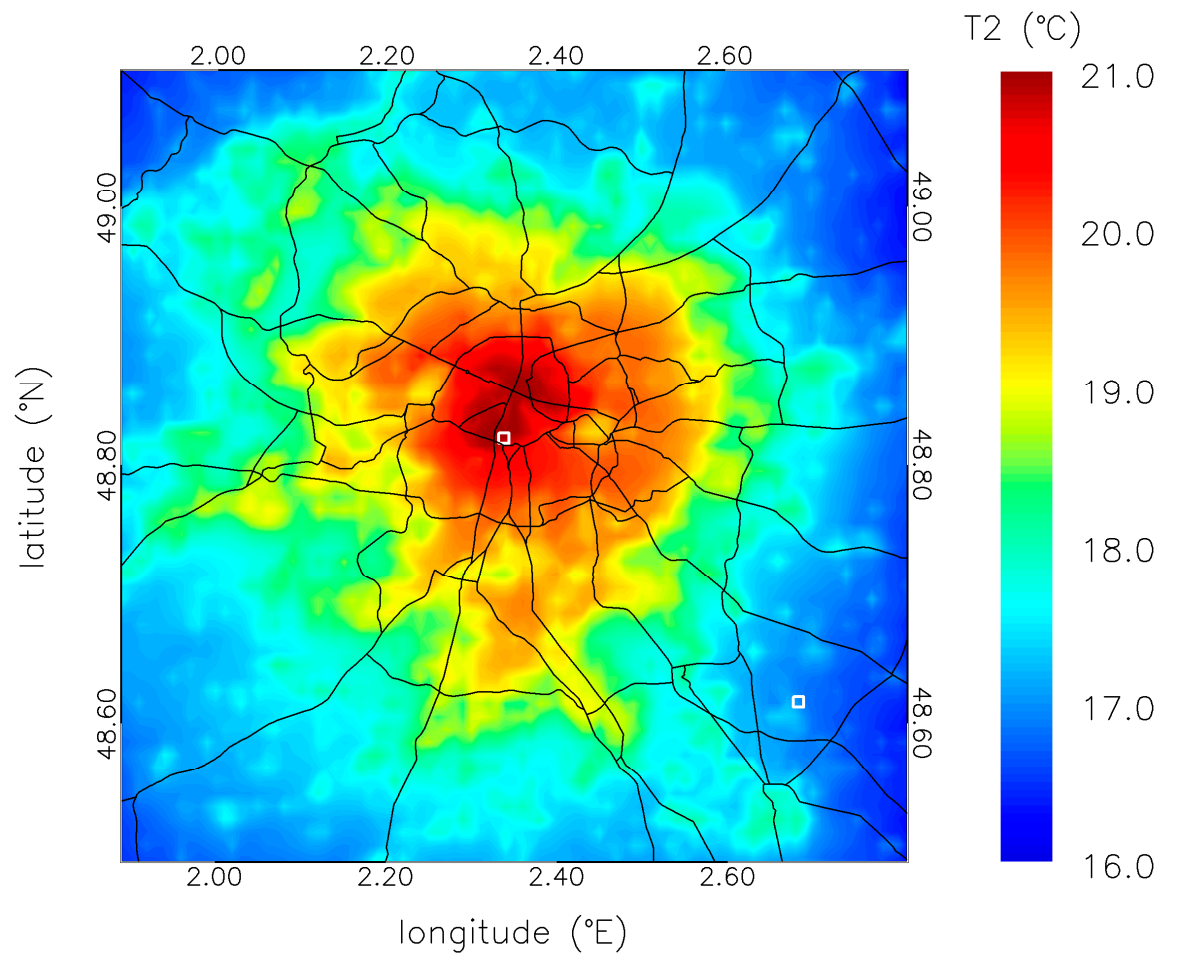

Figure 1. Study domain, centered on the city of Paris. The square white symbols show the positions of the meteorological stations of Paris-Montsouris and Melun-Villaroche. The color pattern shows the nighttime (10 p.m. UT) $2 \mathrm{~m}$ temperature field averaged for the period May-September, as simulated by the model described in Section 3. The solid lines show the highway and main roads.

The analysis conducted here is based on hourly $2 \mathrm{~m}$ air temperature observations at both stations during the period 1 May-30 September 2003. Based on these data we constructed a time series of hourly UHI intensity by taking, for each hour, the temperature value of Paris minus that of Melun. From this, we then extracted the UHI intensity occurring daily at 10 p.m. UT (which corresponds to midnight in local time). The reason for choosing this particular time is that the UHI exhibits the highest intensity in the late evening and early night. Moreover, it has been argued (see, e.g., [11]) that nighttime air temperature is the more relevant quantity in explaining heat-related mortality. The large-scale "ambient" temperature, as a function of which we seek to express the daily evening-time UHI intensity, was taken as the daily temperature occurring in Melun at 2 p.m. UT, at which time the air temperature generally attains its daily maximum value.

The processing described above resulted in 153 daily values of the evening-time (10 p.m.) UHI intensity and afternoon (2 p.m.) air temperature, which will be further denoted UHI22 and T14, respectively. In order to derive robust relations between these two quantities, further processing was done, assigning every day of the considered period to one of four different temperature groups, according to the following T14 temperature range bins: $12-18{ }^{\circ} \mathrm{C}, 18-24{ }^{\circ} \mathrm{C}, 24-30{ }^{\circ} \mathrm{C}$, and $>30{ }^{\circ} \mathrm{C}$. The $6{ }^{\circ} \mathrm{C}$ range used for these temperature bins was found to constitute a fair trade-off between having 
a sufficient number of UHI22 samples in each bin, while still keeping a sufficient number of bins to cover the overall T14 temperature range observed in the period studied. Daily T14 and UHI22 values occurring in each of these groups were averaged to yield four bin-mean values for T14, together with the corresponding mean UHI22 values.

The left panel of Figure 2 shows these bin-averaged UHI22 values as a function of the corresponding T14, together with their standard deviation within each bin. The slope of the regression line of UHI22 against T14 amounts to $0.086{ }^{\circ} \mathrm{C} /{ }^{\circ} \mathrm{C}$. Hence, on average, UHI22 values increase by $0.086{ }^{\circ} \mathrm{C}$ for each ${ }^{\circ} \mathrm{C}$ of increase in T14. The average UHI intensity during the warmest period (approx. $3{ }^{\circ} \mathrm{C}$ for the above- $30{ }^{\circ} \mathrm{C}$ range) is about twice that of the coolest period (approx. $1.5^{\circ} \mathrm{C}$ for the $12-18{ }^{\circ} \mathrm{C}$ range) (Figure 2).
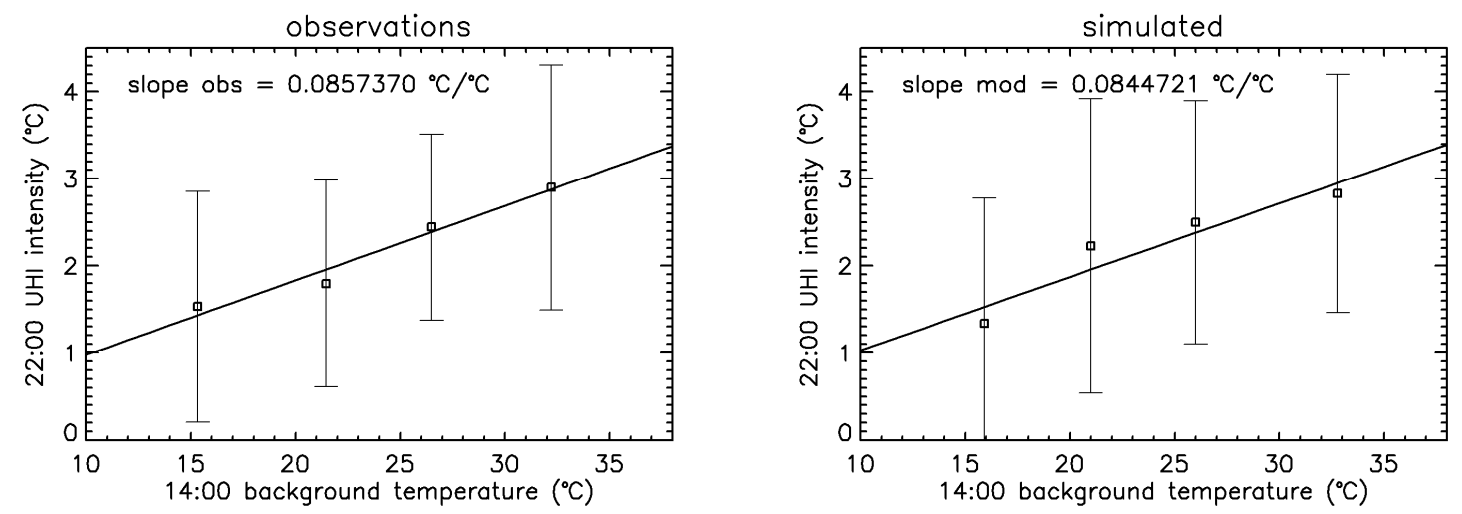

Figure 2. Observed (left) and simulated (right) nighttime (10 p.m. UT) urban-rural temperature difference between the Paris-Montsouris and Melun-Villaroche observational sites, as a function of the daytime (2 p.m. UT) temperature. The error bars denote plus and minus one standard deviation of the temperatures within each temperature bin. While the trends in UHI values between bins are fairly clear, it should be noticed that there is a rather large variance in these data.

While the observations from these two stations yield relevant insights, they obviously contain very incomplete spatial information. More importantly, the urban station (Paris-Montsouris) has a limited representativeness with respect to the UHI intensity of Paris, due to the fact that it is located inside a park. (Unfortunately, data from a station representing truly urban conditions was not available to us for the period studied.) Given the well-known cooling properties of urban green areas, this presumably underestimates the actual UHI intensity in the city's built-up zones. Therefore, we turn towards numerical modeling to complement the observation-based analysis described above.

\section{Simulation}

We conducted a simulation for the larger Paris area for the period May-September 2003, using the prognostic urban climate model extensively described in [25]. This model is composed of a surface energy balance scheme coupled to an atmospheric boundary layer model. The approach is a prognostic one, i.e., starting from an initial state, the model calculates subsequent temperature values for soil, vegetation, the urban substrate, and the overlying air. The main outcome consists of hourly raster files containing relevant meteorological quantities such as the $2 \mathrm{~m}$ air temperature. A particular characteristic of the model is that the surface energy balance scheme is constrained through a data assimilation procedure, using remotely sensed thermal infrared imagery together with a sequential Monte Carlo ("particle filter") approach (see, e.g., [26]).

While there is extensive literature on the subject of mapping air temperature using remotely sensed land surface temperature [27-61], our approach [25] has the advantage that-by its being embedded in a prognostic modeling approach-it yields air temperature also at times when no land surface temperature is available, i.e., in between satellite passes. 
The satellite infrared imagery used in our study was taken from the MODIS archive containing land surface temperature values derived from $1 \mathrm{~km}$ brightness temperature imagery (both daytime and nighttime) acquired by the MODIS instruments on board the TERRA and AQUA platforms. The raw imagery was corrected for atmospheric and surface emissivity effects, as described in [62].

The specification of the required terrain parameters is done based on digital raster files containing CORINE land cover, which is available from the European Environment Agency. The spatial distribution of the vegetation abundance is estimated using MODIS imagery containing the Normalized Difference Vegetation Index (NDVI). Large-scale meteorological conditions are accounted for by forcing the model with external fields of appropriate quantities, such as temperature, wind vector components, and humidity, from the ERA-Interim archive of the European Centre for Medium-Range Weather Forecasting (ECMWF), which was also used to specify the initial soil temperature and volumetric moisture content. Downwelling shortwave and longwave radiation, which is required as an input for the surface energy balance scheme, is specified from geostationary METEOSAT satellite imagery distributed by the Land Surface Analysis Satellite Applications Facility (Land SAF) of EUMETSAT. Further details regarding the urban climate model, including results of validation exercises, are available in $[25,62,63]$.

The urban climate model was run for the wider Paris area, on a domain covering $100 \mathrm{~km} \times 100 \mathrm{~km}$, at a spatial resolution of $1 \mathrm{~km}$. While this resolution is a constraint imposed by the spatial resolution of the MODIS $1 \mathrm{~km}$ thermal satellite imagery, for a large city such as Paris this level of spatial detail is capable of providing an overall temperature pattern at the scale of the agglomeration. As an example, Figure 1 shows the average simulated $2 \mathrm{~m}$ air temperature occurring at 10 p.m. UT during the period May-September 2003.

In order to create confidence in the simulation results, we conducted a validation of the $2 \mathrm{~m}$ air temperature, comparing simulated values with observations from the two meteorological stations (Paris-Montsouris and Melun-Villaroche) described in the previous section. In fact, rather than validating the urban and rural temperatures separately, we concentrated on the validation of the urban-rural temperature increment, because this is the main quantity of interest here.

However, the spatial resolution $(1 \mathrm{~km})$ used in our modeling approach is problematic when comparing simulated temperatures with observed values. Indeed, as mentioned above, the urban observations were taken from a station located inside a park. Given the park's dimensions (around $400 \mathrm{~m}$ across), its surface area occupies only around $16 \%$ of a model grid cell, or less in case it is distributed over adjacent grid cells. In order to account for this discrepancy, we designed a simple method to adjust the simulated temperatures for the presence of vegetation, so as to allow a better comparison with the observations acquired in the park.

In this method, we considered hourly temperatures simulated at the grid cells containing the positions of the two meteorological stations. For the urban station, we also extracted the hourly simulated temperature of the eight surrounding grid cells, thus yielding a total of nine simulated urban temperature values for every hour of the concerned period. With these temperatures, we then calculated nine hourly UHI intensity time series by subtracting the simultaneous rural values. For each individual hour, we then performed a regression of the nine UHI intensities in the station's neighborhood with respect to the percentage of impermeable surface within each of the nine selected grid cells. The resulting regression coefficients were then employed to extrapolate the central (i.e., at the urban station's position) UHI value to conditions of zero percent impermeable surface, hence mimicking the conditions in the park.

These adjusted temperatures were then averaged by the hour of the day, to yield a mean diurnal cycle for the period May-September 2003. Figure 3 shows the result obtained from the adjusted simulated temperatures, together with the corresponding observed values. The magnitude of the error bars is $0.4^{\circ} \mathrm{C}$, which is a value based on the inter-comparison of co-located thermometric measurements (see $[64,65])$. During most of the day, the model follows the observed values well, except in the early morning (between 4 and 8 a.m. UT). We calculated error statistics for the simulated (against the 
observed) UHI intensity values, yielding a mean absolute error of $0.66^{\circ} \mathrm{C}$, a correlation coefficient of 0.79 , and a bias of $0.49^{\circ} \mathrm{C}$.

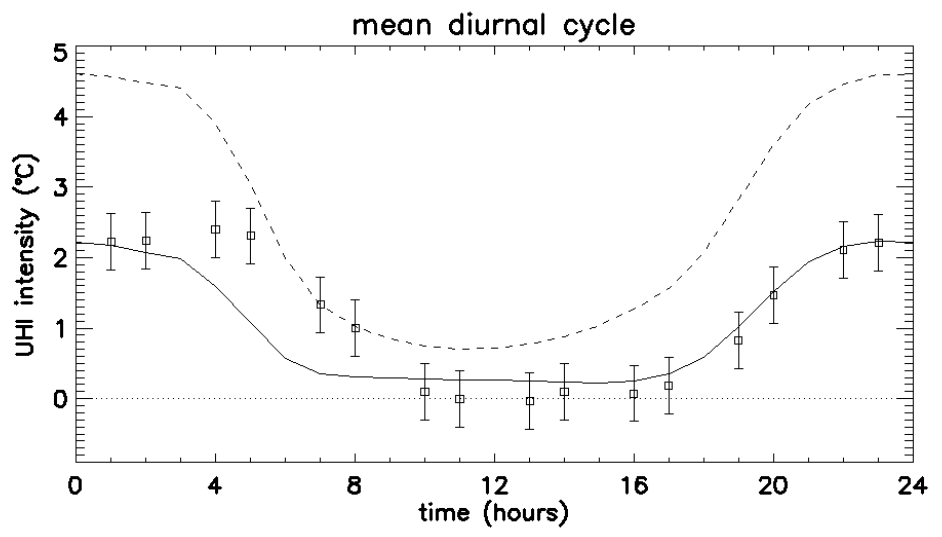

Figure 3. Observed (symbols) and simulated (solid line) mean diurnal cycle of the UHI intensity between Paris-Montsouris and Melun-Villaroche, for the period May-September 2003. The simulated values were adjusted to account for the presence of green vegetation at the Paris-Montsouris station, as explained in the main text. The dashed line shows the non-adjusted simulated value, which corresponds to dense urban substrate.

As a side result, we also calculated the mean diurnal UHI intensity representative of fully urban conditions, i.e., using the regression relations between the hourly UHI intensity and the abundance of impermeable surface in the neighborhood of the urban station, but then extrapolated towards a $100 \%$ impermeable surface, i.e., densely urban conditions. The result is shown in Figure 3 as a dashed line, and the difference with the solid line is a measure for the effect of the park on the average UHI cycle. This result reveals that throughout most of the day, the park exhibits roughly half the UHI intensity of the surrounding dense urban zones, thus confirming the potential of urban green space as a relevant climate adaptation measure.

Since our focus is on the sensitivity of the UHI intensity with respect to background temperature, we also conducted a validation exercise to verify the model's capacity to correctly reproduce the slope of the evening-time UHI (UHI22) intensity versus the afternoon background temperature (T14). Following the same procedure as before (i.e., grouping the background temperatures in four temperature-range categories), we constructed a regression between the simulated UHI22 and T14, the result of which is given in the right-hand panel of Figure 2. With a slope of $0.084{ }^{\circ} \mathrm{C} /{ }^{\circ} \mathrm{C}$, the simulated UHI sensitivity is very close to the observation-based value of $0.086{ }^{\circ} \mathrm{C} /{ }^{\circ} \mathrm{C}$ (see Section 2).

While this result establishes confidence in the model's capacity to reproduce observed UHI effects for Paris, the UHI sensitivity (i.e., the regression slope) shown in Figure 2 is not representative of the dense urban conditions that characterize most of central Paris. Instead, the results only apply to Montsouris Park, in which the urban station is located, and for which we adjusted simulated temperature values. However, our modeling approach, now validated, allows us to assess the UHI sensitivity also for the more densely built-up areas of the city. To do so, for each grid cell in the model domain we calculated a bin-average T14 and corresponding bin-average UHI22 value, again considering the four temperature bins specified previously, i.e., $12-18{ }^{\circ} \mathrm{C}, 18-24{ }^{\circ} \mathrm{C}, 24-30{ }^{\circ} \mathrm{C}$, and $>30^{\circ} \mathrm{C}$. This time, UHI22 was not calculated with respect to the temperature at the Melun station, but with respect to the average temperature of the $1 \%$ coolest grid cells occurring in each of the maps which, from the land cover map used as a basis for the simulations, turned out to be mostly areas covered by short grass. This procedure resulted in four UHI maps for each of the temperature ranges considered, as shown in Figure 4, which clearly shows the effect of the daytime background temperature on the nighttime UHI intensity, the latter becoming stronger during the hotter periods. 

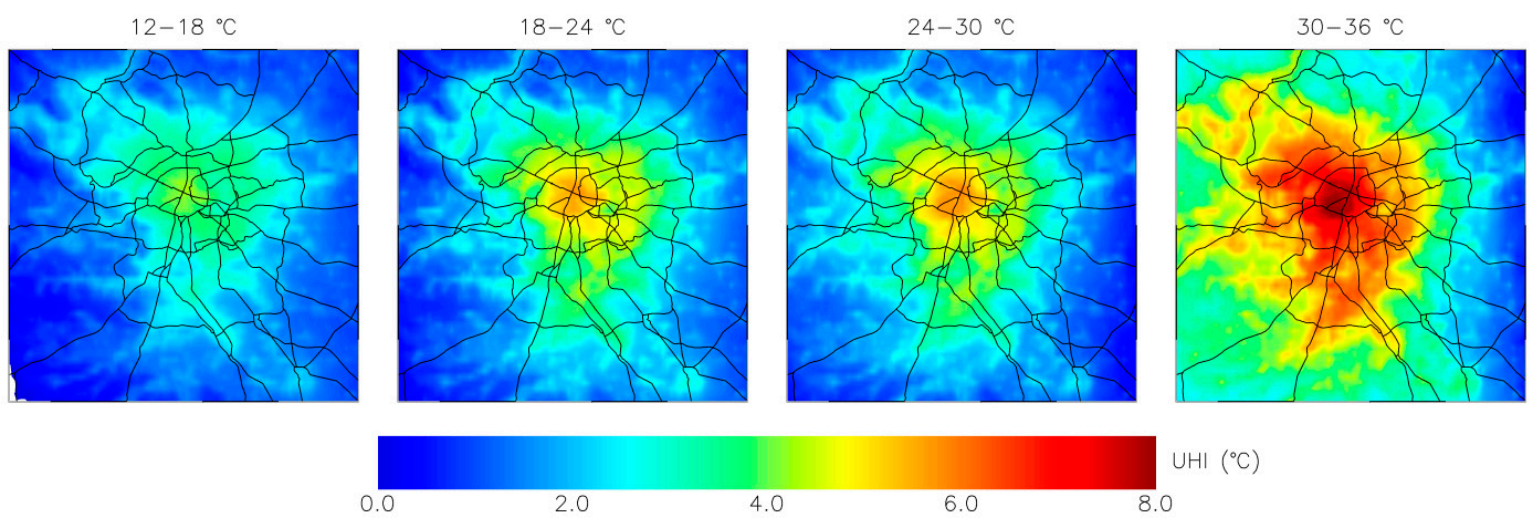

Figure 4. Nighttime (10 p.m. UT) $2 \mathrm{~m}$ air temperature field relative to the average temperature of the $1 \%$ coolest grid cells occurring in the domain. Each panel corresponds to a daytime ( 2 p.m. UT) temperature range as specified above each panel.

Based on the results contained in these maps, we again estimated the sensitivity (regression slope) of UHI22 with respect to T14, calculating UHI22 for each of the four temperature bins as the difference between the average of the $1 \%$ highest and that of the $1 \%$ lowest temperatures occurring within each of the four maps. Performing a regression analysis between UHI22 and T14 as before, we obtained a sensitivity of the UHI intensity to the background temperature of $0.19{ }^{\circ} \mathrm{C} /{ }^{\circ} \mathrm{C}$, which is nearly double the value obtained previously for the Paris-Montsouris and Melun-Villaroche station pair. This means that the more densely built and therefore warmer city quarters of Paris have their UHI intensity increased by $0.19^{\circ} \mathrm{C}$ for each ${ }^{\circ} \mathrm{C}$ increase in the daytime background temperature. In fact, between the coolest $12-18{ }^{\circ} \mathrm{C}$ and hottest $>30{ }^{\circ} \mathrm{C}$ T14 bins, UHI22 values increase from $3.73{ }^{\circ} \mathrm{C}$ to $7.18{ }^{\circ} \mathrm{C}$, respectively, which is also nearly a two-fold difference.

\section{Conclusions}

We conducted an investigation of the relation between the urban-rural temperature increment and background (large-scale) temperatures for the wider Paris area during the period of May-September 2003, when a major heat wave occurred.

In a first step, use was made of meteorological measurements from the Montsouris station in Paris, and from the nearby rural station at Melun-Villaroche. From this, we found a sensitivity of the nocturnal $\mathrm{UHI}$ of $0.086{ }^{\circ} \mathrm{C}$ per ${ }^{\circ} \mathrm{C}$ in daytime temperature. The main limitation of this observation-based analysis resided in the fact that the urban temperature measurements were taken from a meteorological station located inside an urban park, thus not representing the climatic conditions occurring in the built-up portions of the city well.

To address this issue, we conducted urban climate simulations for the wider Paris area at $1 \mathrm{~km}$ resolution. Simulation results were validated for (1) the mean diurnal cycle of the UHI intensity (i.e., the urban-rural temperature contrast); and (2) the sensitivity (regression slope) of the nocturnal UHI intensity with respect to the daytime temperature. In the process of this validation, we applied a regression-based correction to the simulated temperatures to allow a proper comparison with the temperatures in the park, which in the model is a sub-grid feature.

Finally, using the same daytime temperature range bins as for the observation-based analysis, we calculated the sensitivity of the nocturnal UHI intensity with respect to the daytime temperature, this time without the correction for the presence of vegetation at the Paris-Montsouris site, hence representing actual urban conditions.

This sensitivity was found to amount to approximately $0.19{ }^{\circ} \mathrm{C} /{ }^{\circ} \mathrm{C}$, meaning that per ${ }^{\circ} \mathrm{C}$ increase in the daytime temperature, the nighttime UHI intensity increases by $0.19^{\circ} \mathrm{C}$. Over a daytime temperature range of a few tens of degrees, this yields several ${ }^{\circ} \mathrm{C}$ difference in $\mathrm{UHI}$ intensity. During 
the hottest days occurring in the summer of 2003, the nighttime UHI intensity amounted to almost twice the value encountered during the coolest period.

Based on the above, the main conclusion is that not only are ambient temperatures increased during heat waves, but the latter also intensify the difference between urban and rural temperatures. While we did not investigate this, it can be understood by the fact that the conditions typically inducing strong urban heat islands (clear skies, low wind speed) are generally also those that characterize heat waves.

As a result, there is cause for concern regarding the urban heat island effect in shaping future levels of heat stress, especially considering the projections regarding more frequent, longer-lasting, and more intense heat waves. However, while studies on global and regional (extreme) temperature changes abound, a comparatively modest amount of research has been devoted to urban climate projections.

Furthermore, the results show that for the cooler parts of the urban fabric (e.g., parks), the UHI intensification during heat waves is around half of that of the dense urban fabric, thus providing some insights into possible mitigation strategies for the future.

Finally, despite the fact that our analysis is limited to Paris during the summer of 2003, it clearly adds to the evidence presented by $[13,14]$.

Acknowledgments: We would like to acknowledge support from the European Space Agency's Data User Element (DUE) programme under contract number 21913/08/I-LG (Urban Heat Island and Urban Thermography), the European Community's 7th Framework Programme under grant agreements nos. 308497 (RAMSES) and 308299 (NACLIM), and the Belgian Science Policy Office under contract BR/143/A2 (CORDEX.be).

Author Contributions: Koen De Ridder and Bino Maiheu developed the numerical model used, and Dirk Lauwaet conducted simulation experiments with it. Ioannis Daglis, Iphigenia Keramitsoglou, Kostas Kourtidis, and Paolo Manunta processed the satellite infrared imagery required as input for the urban climate model. Koen De Ridder and Marc Paganini were in charge of the overall design of the study, and the analyses and paper writing were done by Koen De Ridder.

Conflicts of Interest: The authors declare no conflict of interest.

\section{References}

1. Meehl, G.A.; Tebaldi, C. More intense, more frequent and longer lasting heat waves in the 21st century. Nature 2004, 305, 994-997. [CrossRef] [PubMed]

2. Diffenbaugh, N.S.; Giorgi, F. Climate change hotspots in the CMIP5 global climate model ensemble. Clim. Chang. 2012, 114, 813-822. [CrossRef] [PubMed]

3. Schär, C.; Vidale, P.L.; Luthi, D.; Frei, C.; Haberli, C.; Liniger, M.A.; Appenzeller, C. The role of increasing temperature variability in European Summer heat waves. Nature 2004, 427, 332-336. [CrossRef] [PubMed]

4. Borden, K.A.; Cutter, S.L. Spatial patterns of natural hazards mortality in the United States. Int. J. Health Geograph. 2008, 7, 64. [CrossRef] [PubMed]

5. Beven, J.L., II; Avila, L.A.; Blake, E.S.; Brown, D.P.; Franklin, J.L.; Knabb, R.D.; Pasch, R.J.; Rhome, J.R.; Stewart, S.R. Atlantic Hurricane Season of 2005. Mon. Weather Rev. 2008, 136, 1109-1173. [CrossRef]

6. Robine, J.-M.; Cheung, S.L.K.; le Roy, S.; van Oyen, H.; Griffiths, C.; Michel, J.-P.; Herrmann, F.R. Death toll exceeded 70,000 in Europe during the summer of 2003. Comptes Rendus Biol. 2008, 331, 171-178. [CrossRef] [PubMed]

7. Saha, M.V.; Davis, R.E.; Hondula, D.M. Mortality displacement as a function of heat event strength in 7 US cities. Am. J. Epidemiol. 2014, 179, 467-744. [CrossRef] [PubMed]

8. Toulemon, L.; Barbieri, M. The mortality impact of the August 2003 heat wave in France: Investigating the "harvesting" effect and other long-term consequences. Popul. Stud. 2008, 62, 39-53. [CrossRef] [PubMed]

9. Keller, R.C. Fatal isolation: The Devastating Paris Heat Wave of 2003; University of Chicago Press: Chicago, IL, USA, 2015; p. 240.

10. Gabriel, K.M.A.; Endlicher, W.R. Urban and rural mortality rates during heat waves in Berlin and Brandenburg, Germany. Environ. Poll. 2011, 159, 2044-2050. [CrossRef] [PubMed]

11. Dousset, B.; Gourmelon, F.; Laaidi, K.; Zeghnoun, A.; Giraudet, E.; Bretin, P.; Maurid, E.; Vandentorren, S. Satellite monitoring of summer heat waves in the Paris metropolitan area. Int. J. Climatol. 2011, 31, 313-323. [CrossRef] 
12. Vandentorren, S.; Suzan, F.; Medina, S.; Pascal, M.; Maulpoix, A.; Cohen, J.-C.; Ledrans, M. Mortality in 13 French cities during the August 2003 heatwave. Am. J. Public Health 2004, 94, 1518-1520. [CrossRef] [PubMed]

13. Ho, H.C.; Knudby, A.; Walker, B.B.; Henderson, S.B. Delineation of Spatial Variability in the Temperature-Mortality Relationship on Extremely Hot Days in Greater Vancouver, Canada. Environ. Health Perspect. 2016. [CrossRef] [PubMed]

14. Guo, Y.; Barnett, A.G.; Tong, S. Spatiotemporal model or time series model for assessing city-wide temperature effects on mortality? Environ. Res. 2013, 120, 55-62. [CrossRef] [PubMed]

15. Hattis, D.; Ogneva-Himmelberger, Y.; Ratick, S. The spatial variability of heat-related mortality in Massachusetts. Appl. Geogr. 2012, 33, 45-52. [CrossRef]

16. Hondula, D.M.; Davis, R.E. The predictability of high-risk zones for heat-related mortality in seven US cities. Nat. Hazards 2014, 74, 771-788. [CrossRef]

17. Hondula, D.M.; Davis, R.E.; Leisten, M.J.; Saha, M.V.; Veazey, L.M.; Wegner, C.R. Fine-scale spatial variability of heat-related mortality in Philadelphia County, USA, from 1983-2008: A case-series analysis. Environ. Health 2012, 11, 16. [PubMed]

18. Vaneckova, P.; Beggs, P.J.; Jacobson, C.R. Spatial analysis of heat-related mortality among the elderly between 1993 and 2004 in Sydney, Australia. Soc. Sci. Med. 2010, 70, 293-304. [CrossRef] [PubMed]

19. Vargo, J.; Stone, B.; Habeeb, D.; Liu, P.; Russell, A. The social and spatial distribution of temperature-related health impacts from urban heat island reduction policies. Environ. Sci. Policy 2016, 66, 366-374.

20. Zhu, Q.; Liu, T.; Lin, H.; Xiao, J.; Luo, Y.; Zeng, W.; Zeng, S.; Wei, Y.; Chu, C.; Baum, S.; et al. The spatial distribution of health vulnerability to heat waves in Guangdong Province, China. Glob. Health Action 2014, 7, 25051. [CrossRef] [PubMed]

21. Stone, B. The City and the Coming Climate. Climate Change in the Places We Live; Cambridge University Press: Cambridge, UK, 2012; p. 206.

22. Li, D.; Bou-Zeid, E. synergistic interactions between urban heat islands and heat waves: The impact in cities is larger than the sum of its parts. J. Appl. Meteorol. Climatol. 2013, 52, 2051-2064.

23. Li, D.; Sun, T.; Liu, M.; Yong, L.; Wang, L.; Gao, Z. Contrasting responses of urban and rural surface energy budgets to heat waves explain synergies between urban heat islands and heat waves. Environ. Res. Lett. 2015, 10, 054009.

24. Schatz, J.; Kucharik, C.J. Urban climate effects on extreme temperatures in Madison, Wisconsin, USA. Environ. Res. Lett. 2015, 10, 094024. [CrossRef]

25. Maiheu, B.; de Ridder, K.; Dousset, B.; Manunta, P.; Ceriola, G.; Viel, M.; Daglis, I.; Keramitsoglou, I.; Ginannaros, T.; Melas, D.; et al. Modelling air temperature via assimilation of satellite derived surface temperature within the Urban Heat Island project. In Proceedings of the Joint SIG Workshop, European Association of Remote Sensing Laboratories (EARSeL), Ghent, Belgium, 22-24 September 2010; pp. 162-181.

26. Doucet, A.; de Freitas, N.; Gordon, N.J. (Eds.) Sequential Monte Carlo Methods in Practice; Springer: New York, NY, USA, 2001; p. 582.

27. Bechtel, B.; Wiesner, S.; Zakšek, K. Estimation of dense time series of urban air temperatures from multitemporal geostationary satellite data. IEEE J. Sel. Top. Appl. Earth Obs. Remote Sens. 2014, 7, 4129-4137. [CrossRef]

28. Benali, A.; Carvalho, A.C.; Nunes, J.P.; Carvalhais, N.; Santos, A. Estimating air surface temperature in Portugal using MODIS LST data. Remote Sens. Environ. 2012, 124, 108-121. [CrossRef]

29. Chen, F.; Liu, Y.; Liu, Q.; Qin, F. A statistical method based on remote sensing for the estimation of air temperature in China. Int. J. Climatol. 2015, 35, 2131-2143. [CrossRef]

30. Cristóbal, J.; Ninyerola, M.; Pons, X. Modeling air temperature through a combination of remote sensing and GIS data. J. Geophys. Res. Atmosp. 2008, 113. [CrossRef]

31. Emamifar, S.; Rahimikhoob, A.; Noroozi, A.A. Daily mean air temperature estimation from MODIS land surface temperature products based on M5 model tree. Int. J. Climatol. 2013, 33, 3174-3181. [CrossRef]

32. Guo, Z.; Chen, Y.; Cheng, M.; Jiang, H. Near-surface air temperature retrieval from Chinese Geostationary FengYun Meteorological Satellite (FY-2C) data. Int. J. Remote Sens. 2014, 35, 3892-3914. [CrossRef]

33. Ho, H.C.; Knudby, A.; Sirovyak, P.; Xu, Y.; Hodul, M.; Henderson, S.B. Mapping maximum urban air temperature on hot summer days. Remote Sens. Environ. 2014, 154, 38-45. [CrossRef] 
34. Ho, H.C.; Knudby, A.; Xu, Y.; Hodul, M.; Aminipouri, M. A comparison of urban heat islands mapped using skin temperature, air temperature, and apparent temperature (Humidex), for the greater Vancouver area. Sci. Total Environ. 2016, 544, 929-938. [CrossRef] [PubMed]

35. Holden, Z.A.; Abatzoglou, J.T.; Luce, C.H.; Baggett, L.S. Empirical downscaling of daily minimum air temperature at very fine resolutions in complex terrain. Agric. Forest Meteorol. 2011, 151, 1066-1073. [CrossRef]

36. Hou, P.; Chen, Y.; Qiao, W.; Cao, G.; Jiang, W.; Li, J. Near-surface air temperature retrieval from satellite images and influence by wetlands in urban region. Theor. Appl. Climatol. 2013, 111, 109-118. [CrossRef]

37. Huang, R.; Zhang, C.; Huang, J.; Zhu, D.; Wang, L.; Liu, J. Mapping of daily mean air temperature in agricultural regions using daytime and nighttime land surface temperatures derived from Terra and Aqua MODIS data. Remote Sens. 2015, 7, 8728-8756. [CrossRef]

38. Janatian, N.; Sadeghi, M.; Sanaeinejad, S.H.; Bakhshian, E.; Farid, A.; Hasheminia, S.M.; Ghazanfari, S. A statistical framework for estimating air temperature using MODIS land surface temperature data. Int. J. Climatol. 2016. [CrossRef]

39. Kloog, I.; Chudnovsky, A.; Koutrakis, P.; Schwartz, J. Temporal and spatial assessments of minimum air temperature using satellite surface temperature measurements in Massachusetts, USA. Sci. Total Environ. 2012, 432, 85-92. [CrossRef] [PubMed]

40. Kloog, I.; Nordio, F.; Coull, B.A.; Schwartz, J. Predicting spatiotemporal mean air temperature using MODIS satellite surface temperature measurements across the Northeastern USA. Remote Sens. Environ. 2014, 150, 132-139. [CrossRef]

41. Lin, S.; Moore, N.J.; Messina, J.P.; DeVisser, M.H.; Wu, J. Evaluation of estimating daily maximum and minimum air temperature with MODIS data in east Africa. Int. J. Appl. Earth Obs. Geoinf. 2012, 18, 128-140. [CrossRef]

42. Mao, K.B.; Tang, H.J.; Wang, X.F.; Zhou, Q.B.; Wang, D.L. Near-surface air temperature estimation from ASTER data based on neural network algorithm. Int. J. Remote Sens. 2008, 29, 6021-6028. [CrossRef]

43. Mostovoy, G.V.; King, R.L.; Reddy, K.R.; Kakani, V.G.; Filippova, M.G. Statistical estimation of daily maximum and minimum air temperatures from MODIS LST data over the state of Mississippi. GISci. Remote Sens. 2006, 43, 78-110. [CrossRef]

44. Nichol, J.E.; Fung, W.Y.; Lam, K.S.; Wong, M.S. Urban heat island diagnosis using ASTER satellite images and "in situ" air temperature. Atmos. Res. 2009, 94, 276-284. [CrossRef]

45. Nichol, J.E.; Wong, M.S. Spatial variability of air temperature and appropriate resolution for satellite-derived air temperature estimation. Int. J. Remote Sens. 2008, 29, 7213-7223. [CrossRef]

46. Prihodko, L.; Goward, S.N. Estimation of air temperature from remotely sensed surface observations. Remote Sens. Environ. 1997, 60, 335-346. [CrossRef]

47. Şahin, M. Modelling of air temperature using remote sensing and artificial neural network in Turkey. Adv. Space Res. 2012, 50, 973-985. [CrossRef]

48. Shen, S.; Leptoukh, G.G. Estimation of surface air temperature over central and eastern Eurasia from MODIS land surface temperature. Environ. Res. Lett. 2011, 6, 045206. [CrossRef]

49. Shi, L.; Liu, P.; Kloog, I.; Lee, M.; Kosheleva, A.; Schwartz, J. Estimating daily air temperature across the Southeastern United States using high-resolution satellite data: A statistical modeling study. Environ. Res. 2016, 146, 51-58. [CrossRef] [PubMed]

50. Stisen, S.; Sandholt, I.; Nørgaard, A.; Fensholt, R.; Eklundh, L. Estimation of diurnal air temperature using MSG SEVIRI data in West Africa. Remote Sens. Environ. 2007, 110, 262-274. [CrossRef]

51. Sun, H.; Chen, Y.; Gong, A.; Zhao, X.; Zhan, W.; Wang, M. Estimating mean air temperature using MODIS day and night land surface temperatures. Theor. Appl. Climatol. 2014, 118, 81-92. [CrossRef]

52. Sun, Y.J.; Wang, J.F.; Zhang, R.H.; Gillies, R.R.; Xue, Y.; Bo, Y.C. Air temperature retrieval from remote sensing data based on thermodynamics. Theor. Appl. Climatol. 2005, 80, 37-48. [CrossRef]

53. Vancutsem, C.; Ceccato, P.; Dinku, T.; Connor, S.J. Evaluation of MODIS land surface temperature data to estimate air temperature in different ecosystems over Africa. Remote Sens. Environ. 2010, 114, 449-465. [CrossRef]

54. Xu, Y.; Knudby, A.; Ho, H.C. Estimating daily maximum air temperature from MODIS in British Columbia, Canada. Int. J. Remote Sens. 2014, 35, 8108-8121. [CrossRef] 
55. Xu, Y.; Liu, Y. Monitoring the Near-surface Urban Heat Island in Beijing, China by Satellite Remote Sensing. Geogr. Res. 2015, 53, 16-25. [CrossRef]

56. Xu, Y.; Qin, Z.; Shen, Y. Study on the estimation of near-surface air temperature from MODIS data by statistical methods. Int. J. Remote Sens. 2012, 33, 7629-7643. [CrossRef]

57. Yan, H.; Zhang, J.; Hou, Y.; He, Y. Estimation of air temperature from MODIS data in east China. Int. J. Remote Sens. 2009, 30, 6261-6275. [CrossRef]

58. Yang, G.; Pu, R.; Huang, W.; Wang, J.; Zhao, C. A novel method to estimate subpixel temperature by fusing solar-reflective and thermal-infrared remote-sensing data with an artificial neural network. IEEE Trans. Geosci. Remote Sens. 2010, 48, 2170-2178. [CrossRef]

59. Yao, Y.; Zhang, B. MODIS-based estimation of air temperature of the Tibetan Plateau. J. Geogr. Sci. 2013, 23, 627-640. [CrossRef]

60. Zakšek, K.; Schroedter-Homscheidt, M. Parameterization of air temperature in high temporal and spatial resolution from a combination of the SEVIRI and MODIS instruments. ISPRS J. Photogramm. Remote Sens. 2009, 64, 414-421. [CrossRef]

61. Zhu, W.; Lu, A.; Jia, S. Estimation of daily maximum and minimum air temperature using MODIS land surface temperature products. Remote Sens. Environ. 2013, 130, 62-73. [CrossRef]

62. Keramitsoglou, I.; Daglis, I.A.; Amiridis, V.; Chrysoulakis, N.; Ceriola, G.; Manunta, P.; Maiheu, B.; de Ridder, K.; Lauwaet, D.; Paganini, M. Evaluation of satellite-derived products for the characterization of the urban thermal environment. J. Appl. Remote Sens. 2012, 6, 061704. [CrossRef]

63. Keramitsoglou, I.; Kiranoudis, C.T.; Maiheu, B.; de Ridder, K.; Daglis, I.A.; Manunta, P.; Paganini, M. Heat wave hazard classification and risk assessment using artificial intelligence fuzzy logic. Environ. Monit. Assess. 2013. [CrossRef] [PubMed]

64. Brandsma, T.; van der Meulen, J.P. Thermometer screen intercomparison in De Bilt (The Netherlands)—Part II: Description and modeling of mean temperature differences and extremes. Int. J. Climatol. 2008, 28, 389-400. [CrossRef]

65. De Ridder, K.; Lauwaet, D.; Maiheu, B. UrbClim-A fast urban boundary layer climate model. Urban Clim. 2015, 12, 21-48. [CrossRef]

(C) 2016 by the authors; licensee MDPI, Basel, Switzerland. This article is an open access article distributed under the terms and conditions of the Creative Commons Attribution (CC-BY) license (http://creativecommons.org/licenses/by/4.0/). 